\title{
Seroprevalence of Bartonella henselae and Toxoplasma gondii among Healthy Individuals in Thailand
}

\author{
Soichi MARUYAMA, Sumalee BOONMAR ${ }^{1)}$, Yukio MORITA ${ }^{2)}$, Takeo SAKAI ${ }^{3)}$, Shigeo TANAKA ${ }^{4}$, \\ Fukumitsu YAMAGUCHI ${ }^{5}$, Hidenori KABEYA and Yasuji KATSUBE
}

\begin{abstract}
Laboratories of Veterinary Public Health, ${ }^{3)}$ Veterinary Surgery, and ${ }^{4)}$ Preventive Medicine and Animal Health, Department of Veterinary Medicine, College of Bioresource Sciences, Nihon University, 1866 Kameino, Fujisawa, Kanagawa 252-8510, Japan, ${ }^{1)}$ Faculty of Veterinary Medicine, Kasetsart University, Bangkok 10903, Thailand, ${ }^{2}$ Chuou Meat Inspection Center, Gunma Prefecture, Tamamuramachi, Sawa-gun, Gunma 370-1100 and ${ }^{5}$ First Department of Oral Surgery, School of Dentistry at Matsudo, Nihon University, 2-870-1 Sakae-cho-nishi, Matsudo, Chiba 271-8587, Japan
\end{abstract}

(Received 10 October 1999/Accepted 24 January 2000)

ABSTRACT. The seroprevalence of Bartonella henselae and Toxoplasma gondii among apparently healthy individuals, mainly blood donors, in Thailand was investigated by an indirect fluorescent antibody technique and by a latex agglutination test, respectively. Of 163 serum samples examined, 9 (5.5\%) were found to be positive for B. henselae-IgG, $2(1.2 \%)$ for B. henselae-IgM, and $5(3.1 \%)$ for the $T$. gondii antibody. No significant difference was observed between male and female samples in the serological test with either $B$. henselae or T. gondii. The age of individuals with $B$. henselae- $\operatorname{IgG}$ was distributed from the $20 \mathrm{~s}$ to the $70 \mathrm{~s}$, and $B$. henselae- $\operatorname{IgM}$ was found in the individuals of the $30 \mathrm{~s}$ and $60 \mathrm{~s}$. The age of $T$. gondii positive samples ranged from the $20 \mathrm{~s}$ to the $60 \mathrm{~s}$. In this study, the prevalence of $B$. henselae infection among healthy individuals in Thailand was serologically demonstrated for the first time.-KEY wORDS: antibody, Bartonella henselae, Thailand.

J. Vet. Med. Sci. 62(6): 635-637, 2000

Cat scratch disease (CSD) and toxoplasmosis are worldwide zoonoses [3, 6-8, 14, 16, 19-22], and cats are regarded as one of major reservoirs of both diseases $[4,11$, $13,15,21]$. Since Thailand is a country of devout Hinayana Buddhism, there are many temples that keep free-living dogs and cats in the precincts. Furthermore, many Thai people keep cats freely in their house and yard. The cat population in Thailand is estimated to be around 2 million. However, little is known about the infectious status of both CSD and toxoplasmosis in human populations in Thailand, especially, the prevalence of CSD. In this paper, the authors conducted a serological investigation on both Bartonella henselae and Toxoplasma gondii infections among healthy human populations in Thailand.

Between 1997 and 1998, a total of 163 serum samples (57 males, 106 females) were collected from apparently healthy individuals, mainly blood donors, at the Faculty of Medicine, Thammasart University in Bangkok. The age of the individuals varied from 2 to 89 years old. After the blood collection, the serum was immediately separated by centrifugation and stored in $\mathrm{a}-30^{\circ} \mathrm{C}$ freezer. The serum samples were sent to the Laboratory of Veterinary Public Health, College of Bioresource Sciences, Nihon University under frozen conditions, and they were stored at $-85^{\circ} \mathrm{C}$ until examined.

The antibody titers to $B$. henselae were determined by immunofluorescent antibody technique (IFA) with the antigen of $B$. henselae (ATCC 49882). The antigen slides were made by a procedure reported previously [15]. The frozen sera were thawed at room temperature and treated at $56^{\circ} \mathrm{C}$ for $30 \mathrm{~min}$ in order to inactivate them. Fluorescein- conjugated goat anti-human IgG or fluorescein-conjugated goat anti-human IgM (Cappel Research Products, Organon Teknika Corp, U.S.A.) were used as a second antibody to detect the IgG or IgM antibody, respectively. The former was diluted 1:400 and the latter 1:40 in sterile phosphate buffered saline (PBS) with $0.001 \%$ Evan's blue. For detection of the $\mathrm{IgG}$ antibody, the serum samples were diluted by $10 \%$ skim milk in PBS without Evan's blue and screened at 1:32 and 1:64. Any sample positive at 1:64 dilution was titrated further in a series of twofold dilutions up to $1: 1,024$. The IgM antibody was screened at 1:8 and $1: 16$ and titrated in the same manner as the IgG antibody mentioned above. The intensity of the bacillus-specific fluorescence was scored subjectively from 1 to 4 , and a fluorescence score of $\geqq 2$ was considered to be positive at a dilution of $\geqq 1: 64$ for the $\operatorname{IgG}$ and $\geqq 1: 16$ for the $\operatorname{IgM}$ antibody.

The antibody including $\operatorname{IgG}$ and $\operatorname{IgM}$ against $T$. gondii was examined with a latex agglutination test (LAT) kit (Toxo Check; Eiken Chemical Co., Ltd., Japan) with microtitre plates (U-shaped wells). A titer of $\geqq$ 1:64 was considered to be positive. The results obtained from IFA and LAT were analyzed statistically by the $\chi^{2}$ test.

The IgG antibody to B. henselae was found in $5.5 \%$ (9/ $163)$ of the individuals examined. The positivity was $7.0 \%$ $(4 / 57)$ in males and $4.7 \%(5 / 106)$ in females, showing no significant difference between them. Only $1.2 \%(2 / 163)$ of the individuals tested were positive for the $\operatorname{IgM}$ antibody against $B$. henselae. The rate in males and females was $1.8 \%(1 / 57)$ and $0.9 \%(1 / 106)$, respectively. The seroprevalence of $T$. gondii was demonstrated to be $3.1 \%$ 
Table 1 . Antibody prevalence against $B$. henselae and $T$. gondii among healthy individuals in Thailand in relation to genders

\begin{tabular}{ccccc}
\hline \multirow{2}{*}{ Gender } & No. examined & \multicolumn{3}{c}{ No. (\%) positive for: } \\
\cline { 3 - 5 } & & B. henselae-IgG & B. henselae-IgM & T. gondii \\
\hline Male & 57 & $4(7.0)$ & $1(1.8)$ & $2(3.5)$ \\
Female & 106 & $5(4.7)$ & $1(0.9)$ & $3(2.8)$ \\
\hline Total & 163 & $9(5.5)$ & $2(1.2)$ & $5(3.1)$ \\
\hline
\end{tabular}

Table 2. Antibody prevalence of $B$. henselae and $T$. gondii among healthy individuals in Thailand in relation to various age groups

\begin{tabular}{ccccc}
\hline \multirow{2}{*}{ Age group } & $\begin{array}{c}\text { No. } \\
\text { examined }\end{array}$ & \multicolumn{4}{c}{ No. positive for: } \\
\cline { 3 - 5 } & & B. henselae-IgG & B. henselae-IgM & T. gondii \\
\hline$<10 \mathrm{~s}$ & 2 & 0 & 0 & 0 \\
$10 \mathrm{~s}$ & 17 & 0 & 0 & 0 \\
$20 \mathrm{~s}$ & 35 & $3(128,128,128)^{\mathrm{a})}$ & 0 & $1(256)$ \\
$30 \mathrm{~s}$ & 41 & $2(128,128)$ & $1(16)$ & $1(64)$ \\
$40 \mathrm{~s}$ & 28 & $1(128)$ & 0 & $1(64)$ \\
$50 \mathrm{~s}$ & 17 & 0 & 0 & $1(64)$ \\
$60 \mathrm{~s}$ & 10 & 0 & $1(16)$ & $1(128)$ \\
$>70 \mathrm{~s}$ & 5 & $1(64)$ & 0 & 0 \\
Unknown & 8 & $2(64,128)$ & 0 & 0 \\
\hline Total & 163 & 9 & 2 & 5 \\
\hline
\end{tabular}

a) Figures in parenthesis indicate the antibody titers.

(5/163). The rate for males and females was 3.5\% and 2.8, respectively. For any of the agents examined, no statistical difference was observed between males and females (Table $1)$.

The individuals that had the IgG antibody to $B$. henselae ranged from the $20 \mathrm{~s}$ to the $70 \mathrm{~s}$. The $\mathrm{IgG}$ antibody titer varied from 1:64 to $1: 128$ (Table 2). The age of two individuals that had the $\operatorname{IgM}$ antibody to $B$. henselae was detected in the $30 \mathrm{~s}$ and $60 \mathrm{~s}$ with the titer of 1:16. The age of samples showing the $T$. gondii antibody positive was distributed from the $20 \mathrm{~s}$ to the $60 \mathrm{~s}$. The antibody titer ranged from $1: 64$ to $1: 256$. No individuals who were positive to $B$. henselae were detected from the samples positive to $T$. gondii. Thus, no relationship was observed between the prevalence of the $B$. henselae and $T$. gondii antibodies.

To our knowledge, this is the first report of seroprevalence for the $B$. henselae infection in human populations in Thailand. The overall IgG antibody positive rate against $B$. henselae was found to be $5.5 \%$ in the country. Although the positive rate of males was slightly higher than that of females, there was no statistical difference between both genders.

It is reported that warm and humid environments are associated with higher seroprevalence to $B$. henselae in the cats of U.S.A., suggesting the implication of a possible arthropod vector such as fleas [11]. Although the climate in Thailand is hot and humid throughout the year, the positive rate of $B$. henselae in apparently healthy individuals was almost the same as the prevalence in other countries $[1,5,8$, $17,18,20-22]$. The exception is a report showing a high incidence $(30 \%)$ in healthy German individuals [19]. The seroprevalence of $B$. henselae in veterinary professionals was slightly higher than that of other human populations without any special risk factor [12, 17]. Furthermore, a higher seroprevalence $(12.5 \%)$ against $B$. henselae was reported in healthy individuals with a history of cat exposure in Japan [20] and in suspected CSD patients [18, 19, 21]. Therefore, these facts may indicate that the seroprevalence against $B$. henselae in human populations is associated with frequency of contact and/or exposure with cats rather than climate.

Although the history of cat exposure could not be demonstrated in the human populations examined, three positive individuals with the IgM antibody were found in this study. This data shows that a recent infection with $B$. henselae have occurred shortly before the blood samples had been collected.

The cases of CSD are frequently reported in younger populations $[3,9,10]$. In this study, the $\operatorname{IgG}$ or IgM antibody was found from young to old subjects, suggesting that the infection of $B$. henselae occurs in various age groups in Thailand.

The $T$. gondii antibody prevalence by LAT was found to be $3.0 \%(5 / 174)$ in healthy individuals in Bangkok. In other reports in Thailand, the seropositive rate against $T$. 
gondii has been reported to be $6.4 \%$ by an indirect hemagglutination test (IHT), $6.2 \%$ by IFA in Khon Kaen, the northeastern area, in 1989 [14], $4.6 \%$ by IHA, and $1.2 \%$ by IFA in Chiang Mai, the northern area, in 1984 [16]. These data show that the prevalence of $T$. gondii in healthy human populations in the country varied from $1.2 \%$ to $6.4 \%$. In other Asian countries, the seropositivity of $T$. gondii in human populations ranged from $4 \%$ by IHA in Pakistan to $59 \%$ by IFA in Singapore [7]. Although various factors such as sample size, age, ethnic groups, climate, and serological techniques are associated with the differences of seropositivities of $T$. gondii antibody [2, 7], the prevalence of toxoplasmosis seems to be relatively low in apparently healthy individuals in Bangkok.

No relationship was observed between the seroprevalence to $B$. henselae and $T$. gondii in healthy individuals. This fact may reflect the difference in the route of infection of cat scratch disease and toxoplasmosis in Thailand, though both diseases are closely associated with cats.

ACKNOWLEDGEMENTS. The authors thank Drs. Eisaku Kikuchi, Atsuyuki Shimizu and Takako Inoue at the Laboratory of Veterinary Public Health, Department of Veterinary Medicine, Nihon University for their technical assistance. This study was supported by an Interdisciplinary General Joint Research Grant, Nihon University Research Grants for 1997 and 1998.

\section{REFERENCES}

1. Amerein, M. P., De Briel, D., Jaulhac, B., Meyer, P., Monteil, H. and Piemont, Y. 1996. Clin. Diagn. Lab. Immunol. 3: 200204.

2. Balfour, A. H., Fleck, D. G., Hughes, H. P. and Sharp, D. 1982. J. Clin. Pathol. 35: 228-232.

3. Carithers, H. A. 1985. Am. J. Dis. Cild. 139: 1124-1133.

4. Childs, J. E., Rooney, J. A., Cooper, J. L., Olson, J. G. and Regnery, R. L. 1994. J. Am. Vet. Med. Assoc. 11: 1775-1778.

5. Demers, D. M., Bass, J. W., Vincent, J. M., Person, D. A., Noyes, D. K., Staege, C. M., Samlaska, C. P., Lockwood, N. H., Regnery, R. L. and Anderson, B. E. 1995. J. Pediatr. 127: 23-26.
6. Dolan, M. J., Wong, M. T., Regnery, R. L., Jorgensen, J. H., Garcia, M., Peters, J. and Drehner, D. 1993. Ann. Intern. Med. 118: 331-336.

7. Dubey, J. P. and Beattie, C. P. 1988. CRC Press, Florida, U.S.A.

8. Fumarola, D., Petruzzelli, R., Giuliani, G., Partipilo, M. R. and Pece, S. 1994. Microbiologica 17: 255-258.

9. Hamilton, D. H., Zangwill, K. M., Hadler, J. L. and Cartter, M. L. 1995. J. Infect. Dis. 172: 570-573.

10. Jackson, L. A., Perkins, B. A. and Wenger, J. D. 1993. Am. J. Public Health 83: 1707-1711.

11. Jameson, P., Greene, C., Regnery, R., Dryden, M., Marks, A., Brown, J., Cooper, J. and Glaus, B. 1995. J. Infect. Dis. 172: 1145-1149.

12. Kelly, P. J., Matthewman, L. A., Hayter, D., Downey, S., Wray, K., Bryson, N. R. and Raoult, D. 1996. J. S. Afr. Vet. Assoc. 67: 182-187.

13. Koehler, J. E., Glaser, C. A. and Tappero, J. W. 1994. J. Am. Med. Assoc. 271: 531-535.

14. Maleewong, W., Lulitanond, V., Pipitgool, V., Auwijitaroon, Y., Kuttsarejariya, S. and Morakote, N. 1989. J. Med. Assoc. Thai. 72: 256-259.

15. Maruyama, S., Hiraga, S., Yokoyama, E., Naoi, M., Tsuruoka, Y., Ogura, Y., Tamura, K., Namba, S., Kameyama, Y., Nakamura, S. and Katsube, Y. 1998. J. Vet. Med. Sci. 60: 9971000 .

16. Morakote, N., Thamasonthi, W., Charuchinda, K. and Khamboonruang, C. 1984. Southeast Asian J. Trop. Med. Public Health 15: 80-85.

17. Noah, D. L., Kramer, C. M., Verbsky, M. P., Rooney, J. A., Smith, K. A. and Childs, J. E. 1997. J. Am. Vet. Med. Assoc. 210: 342-344.

18. Regnery, R. L., Olson, J. G., Perkins, B. A. and Bibb, W. 1992. Lancet 339: 1443-1445.

19. Sander, A., Posselt, M., Oberle, K. and Bredt, W. 1998. Clin. Diagnos. Lab. Immunol. 5: 486-490.

20. Tsuneoka, H., Fuji, R., Yamamoto, K., Fujisawa, K., Iino, H. and Tsukahara, M. 1998. J. Jpn. Assoc. Infect. Dis. 73: 90-91.

21. Yoshida, H., Kusaba, N., Omachi, K., Miyazaki, N., Yamawaki, M., Tsuji, Y., Nakahara, K., Sumino, M., Noudomi, M., Shimokawa, Y. and Tanikawa, K. 1996. Microbiol. Immunol. 40: 671-673.

22. Zangwill, K. M., Hamilton, D. H., Perkins, B. A., Regnery, R. L., Plikaytis, B. D., Hadler, J. L., Carter, M. L. and Wenger, J. D. 1993. New Engl. J. Med. 329: 8-13. 